\title{
From the desk to the front-room? The changing spaces of street-level encounters with the state under austerity
}

\author{
Stephen Crossley* \\ Northumbria University
}

\begin{abstract}
The impact of recent welfare reforms and austerity measures have fallen unevenly on different regions and different household types in the UK. These changes are generally referred to as a 'withdrawal' or 'retrenchment' of the state. It is also possible, however, to argue that the state is actually extending its reach into the lives of disadvantaged or 'troubled' families. This article highlights how, in recent years, the site of government interventions into the lives of marginalised populations has progressively shifted from the public spaces of offices, and neighbourhood and community buildings, to the private, domestic spaces of the 'family'. The changing spaces of street-level encounters with the state are characterised as a shift from 'the desk' or 'the counter' to the 'front door' of the family home. The rhetoric surrounding the Troubled Families Programme is examined and some of the political and symbolic functions of the 'front-door' discourse are expounded.
\end{abstract}

Key words: austerity, family intervention, neighbourhoods, street-level bureaucracy, troubled families.

\section{Introduction}

Michael Lipsky's concept of street-level bureaucrats (1980) highlights the role of frontline public sector workers in determining how public policies are enacted, and how citizens 'receive' policies decreed by government agencies. Lipsky argued that it was primarily through interactions with relatively low (or street) level workers such as teachers, police officers, youth workers, housing officers and social workers that members of the public experienced government policies and programmes. Politicians, political advisors and senior civil servants are rarely, if ever, responsible for implementing the programmes that they develop and there is often a mismatch between the intentions of a policy as it is conceived at a national level, and how it is implemented at a local level or 'on the ground'. Street-level workers regularly exercise their discretion and negotiate, adapt, subvert, and sometimes even resist elements of the policies they are tasked with implementing, in order to make them 'fit' the complex lives of individual members of the public that they work with on a daily basis. 
p. 194. From the desk to the front-room? The changing spaces of street-level encounters with the state under austerity

The focus on the 'street-level' interactions between state workers and citizens also reflects a particular view of the spaces in which such encounters take place. 'Streetlevel' research, therefore, often tends to focus on interactions between citizens and public sector workers in public spaces or (local) government buildings (see, for example, DuBois, 2010; Fletcher, 2011), often over a desk or at a counter. Hupe et al (2015: 20) have suggested that street-level research often involves "walking with police officers in downtown areas, spending hours in the waiting rooms of social services departments or joining environmental inspectors while making site visits.'

Jobcentres, health centres, schools, housing offices, police stations, parks and streets are all settings where members of the public encounter state workers, as well as other members of the public who they share common interests and concerns with. At the current time in the UK, and as a result of austerity measures, welfare reforms, and changing relations between central government and local government, these spaces are undergoing changes which impact on the delivery of services to citizens. Many public buildings such as swimming pools, children's centres and libraries are closing, reducing their opening hours or changing their access arrangements, and becoming more 'targeted' in the populations that they work with (Hastings et al., 2015).

Not all encounters between street-level bureaucrats and citizens take place in public settings, however. The private homes of citizens have also long been sites where public services have been delivered and where interventions by the state have taken place. Social workers and health visitors are two groups of public sector workers who have traditionally worked with and visited families in their homes. More recently, developments such as Family Intervention Projects (FIPs), new national programmes such as the Family Nurse Partnership (FNP) and the Troubled Families Programme (TFP), and an increase in the number of health visitors have seen more emphasis placed on working with marginalised families in their own homes.

This article, then, traces a shift from a New Labour desire to intervene in 'deprived' areas at a neighbourhood level, thus 'remaking communities' (Wallace, 2010), to a more recent focus on interventions which target 'the family'. In doing so, it argues that the programme of austerity that is taking place in the UK at the current time cannot be adequately understood as the straightforward retrenchment or withdrawal of the state from its traditional locales. Accompanying this analysis must be a recognition that at the same time the state is withdrawing from some areas, it is also increasing its presence in the domestic and private spaces of the homes of economically marginalised, disadvantaged and vulnerable families - specifically those it identifies as 'troubled'.

The effects of austerity measures on public services, the delivery landscape, and 'street-level' encounters with the state, are set out in the next section, drawing extensively on four comprehensive research reports that examine the uneven impacts of the government's welfare reforms and cuts to local government spending (De Agostini et al., 2015; Innes and Tetlow, 2015; Hastings et al., 2015; Beatty and Fothergill, 2016). The TFP is then introduced and briefly summarised, before attention is drawn to the rhetorical importance of getting 'in through the front door' of the homes of 'troubled families'. The political and symbolic work that the 'front door' discourse performs is then discussed before the article concludes with a discussion drawing on the work of Loïc Wacquant (2009: 312) who argues that neoliberal governance is essentially two-faced, with a 'comely and caring visage toward the middle and upper classes, and a fearsome and frowning mug toward the lower class'. Wacquant suggests that whilst the neoliberal state in austere times does retreat from engagement or interference with the market and the upper-classes, it simultaneously becomes more concerned and interventionist with poor and disadvantaged groups. 
p. 195. From the desk to the front-room? The changing spaces of street-level encounters with the state under austerity

It should be stressed here that the focus here is not on the 'street-level' practice of the TFP (for this, see, for example, Hayden and Jenkins, 2014; Bond-Taylor, 2015; Crossley, 2016a) or, indeed, the supposed effectiveness of the approach (Crossley, 2015). At the heart of this article is an attempt to set out how the state is being remade under the cloak of austerity, both ideologically and materially, partially through the deployment of the concept of 'troubled families' who represent a disproportionate burden on the public purse and who are best worked with inside their own homes.

\section{Street-level bureaucracy under austerity}

In May 2010, a Coalition Government was formed in the UK, made up of the Conservative and Liberal Democrat parties. Both parties were agreed on the need for austerity measures and wide-ranging structural reforms to public services to help the UK economy to recover following the banking crises of 2007-08. The result was, as one commentator noted, a plan which would see the UK 'have the lowest share of public spending among major capitalist economies, including the USA' with 'the welfare state ... under the most severe and sustained attack it has faced' (Taylor-Gooby, 2012). In addition to these austerity measures, the Coalition government also set out to dramatically change the relations between central government and local government, dismantling the architecture of regional government and instead promoting localism and decentralisation agendas. Initiatives such as the Big Society (Harrison and Sanders, 2015), concerns about increasing private sector involvement in the education and health fields, and a more recent interest in a more business-like 'smarter state' (Cameron, 2015) also highlight the intention to change the way public sector services were delivered and perceived.

Welfare reforms have disproportionately impacted on poor families with children and analysis suggests that reforms yet to be implemented will continue this trend (Beatty and Fothergill, 2013; 2016; De Agostini et al., 2015). The withdrawal of local government funding linked to deprivation has resulted in the most disadvantaged areas of the UK being most affected by cuts to local government services (Innes and Tetlow, 2015). Local authorities, aided by the rhetoric of localism and decentralisation and the removal of 'ring-fencing' for certain funding streams, have responded to these cuts in different ways, often attempting to protect services which are viewed as "propoor' (Hastings et al., 2015: 96). Whilst the government adopted the trope of everyone in the country 'being in it together' the research highlighted above demonstrates that the effects of government decisions on public spending were not evenly spread. Such inequity is, however, perhaps unsurprising, given that the Coalition set out no specific policies for neighbourhoods, stopped monitoring spatial inequalities and replaced large scale regeneration programmes with very small scale projects supporting 'community organising' (Lupton and Fitzgerald, 2015: 4).

Using official government data, Beatty and Fothergill (2016: 3) state that the cumulative loss to recipients as a result of the government's welfare reforms since 2010 will be $£ 27$ billion per year by $2020-2021$. In setting out the uneven impact of these reforms, they argue that 'as a general rule, the more deprived the local authority the greater the financial loss' and highlight that ' 83 per cent of the loss from the post2015 reforms ... can be expected to fall on families with dependent children', with losses to lone parents with two or more children estimated to be, on average, $£ 1,750$ per year. Analysis carried out by other researchers supports Beatty and Fothergill's work. De Agostini et al (2015: 5) note that groups including lone parents, large families and children were, on average, 'clear losers' from the Coalition's tax-benefit policy changes. They go on to highlight that 'across the income distribution as a whole, the 
p. 196. From the desk to the front-room? The changing spaces of street-level encounters with the state under austerity

changes were regressive' with the bottom half of the population (in terms of income) losing out whilst the top half gained from the changes. This outcome is, of course, to be expected when reducing support to groups via the welfare system. Poorer people tend to receive proportionately more of their income from social security payments than more affluent groups and so any reductions, 'capping', or removal of 'spare room subsidies' in these payments are going to disproportionately affect poorer groups.

These reforms to the welfare system are not the only austerity measures enacted since 2010. Local authorities have also seen large reductions in their funding. Hastings et al (2015: 5) note that local government has, in fact, 'suffered a faster rate of cuts than most other areas of government spending' with a '27 per cent reduction in the spending power of the sector in England between 2010/11 and 2014/15'. Mirroring the uneven impact of the welfare reforms highlighted above, Innes and Tetlow (2015: 8) note that 'spending cuts were highest in areas where spending was initially highest London, followed by the North East and North West - and generally lower in regions where spending was initially lower'. The areas that saw the largest cuts, then, were the areas that had previously been identified as being comparatively poorer areas and having higher local needs.

Drawing on case studies in four areas, Hastings et al (2015) demonstrate that local authorities have attempted to protect front-line services but that this has not always been possible and, even where it has, these services have not always emerged unscathed. They also note that "small "savings" can make a big difference to poorer individuals' (2015: 105), arguing that a change in opening hours, or changing the day of a service or location of a session can affect people without the resources or flexibility to adapt to or accommodate such changes. Participants in their study noticed reductions in local environmental services which maintained streets, parks and playgrounds, with some residents from disadvantaged neighbourhoods suggesting that their areas had 'been "forgotten" or "abandoned"' (Hastings et al., 2015: 50). The researchers also highlight the value attached to public buildings such as children's centres, leisure centres and libraries (2015: 53-55), and document how the changes to local services impacted on families with young children:

Children and young people's lives can become more limited and constrained they can be isolated at home by the loss of the children's centre or youth club or by the dirtiness of the playpark, or by the rats in the garden. Similarly, young parents can retreat to the home when public transport costs feel prohibitive or it becomes too hard to get to the library or swimming pool.

Official figures on the closure of services and facilities are hard to come by, but a number of separate reports have highlighted the extent of the issues described by Hastings et al. For example, one report drawing on Freedom of Information requests to local authorities stated that over 350 youth centres had closed as a result of cuts to local authorities by 2013 (UNISON, 2014: 5). A report (funded by a public sector union) has suggested that, again, over 350 library 'service points' (including mobile services and static library sites) nationally had closed in the two years immediately following the 2010 election (Davies, 2013: 3). A third of all local authorities 'abandoned "meals on wheels" provision to their elderly and vulnerable older residents in the face of funding cuts' (Butler, 2014). It was estimated that nearly 500 Sure Start Children's Centres had closed during the first three and a half years of the Coalition's term of office (Beattie, 2014), although a more recent analysis, based on a Freedom of Information request, reported that a total of 295 children's centre buildings had closed since 2010 and, in addition to this, there were 731 sites where 'services have either been merged or reduced to such an extent that they technically can no longer be called a children's centre and have been "de-registered"' (Puffett, 2016). 
p. 197. From the desk to the front-room? The changing spaces of street-level encounters with the state under austerity

Whilst these macro changes have been well documented, there has been less attention paid to what they might mean in terms of how and, more precisely, where the state now engages, at a micro (or street) level, with individuals who require its support or assistance at different times. Interactions that used to take place in an interview room in the housing office, at a desk in a job centre, in a play room at a children's centre, or, increasingly, at the counter of a 'customer service centre' or 'hub' are becoming less frequent, as austerity measures bite and online and telephone contacts are preferred by local authorities for reasons of 'efficiency' (Hastings et al., 2015: 61).

The physical spaces, or 'concrete settings', where citizens meet with street-level bureaucrats, also have symbolic importance. In their classic work Regulating the poor, Fox Piven and Cloward (1977: 20) highlight how these rooms and offices in public buildings are spaces where collective grievances against the state and its officials are moulded and articulated. In a similar vein, and in an enlightening examination of relations between The Bureaucrat and the Poor in French welfare offices, Vincent DuBois (2010: 7) has drawn on work by Jacques Chevallier to highlight the important role of the desk in bureaucratic encounters:

The desk is the perfect and most evocative illustration of a distant and authoritative mode of relations: placed in a position to beg or demand, the applicant depends on the goodwill of the civil servant, knowing that they will not be able to cross the material barrier that physically and symbolically isolates [the civil servant] from the public

The desks and counters of neighbourhood buildings or town halls are self-evidently not the only sites where the state operates and nor are the changes discussed above the only ways in which the spaces of the state are shifting. The 'bedroom tax' levied on social housing tenants with a 'spare bedroom', and an overall cap on the amount of benefits a single household can receive have led to parts of London being unaffordable for people living on low incomes or reliant on social security payments (Taylor, 2015). In a speech advocating a 'smarter' state, David Cameron argued for selling off innercity prisons (using the money to build larger, 'out-of-town' replacements) and proposed '[c]losing down government offices and releasing government land [to] help build more homes and spread home ownership' (Cameron, 2015). People attempting to claim the new 'Universal Credit' benefit are expected to do so online, rather than via a face-toface interaction with a Jobcentre Plus worker, with the Department for Work and Pensions (DWP, 2015) stating that 'most people will apply online and manage their claim through an online account'.

Whilst one must be careful when drawing parallels between the UK and the USA, the effect of the government's welfare 'reforms' and the withdrawal of the state from certain spaces in the UK is reminiscent of the situation described by Wacquant (2008: 83, emphasis added) in his account of 'political marginality' and the 'planned shrinkage of the inner city' in the United States. He argues that the 'neglect of the ghetto orchestrated by federal and local authorities does not stop at welfare policy but extends to the gamut of services aimed at disadvantaged populations'. In earlier work with Wacquant, Pierre Bourdieu suggests that ghettos are 'abandoned sites that are fundamentally characterised by absence - basically, that of the state and of everything that comes with it, police, schools, health care institutions, associations etc.' (Bourdieu et al., 1999: 123, original emphasis). The withdrawal of the state from certain areas and public spaces in the UK is not, however, the totality of the austerity story. Simultaneous developments have seen the expansion of state activity into other spaces, with the state identifying family homes and family life as sites of intervention to address numerous 'social problems' (Cameron, 2010; 2014). 
p. 198. From the desk to the front-room? The changing spaces of street-level encounters with the state under austerity

In 2011, in the first ever UK government child poverty strategy, a commitment was made to provide an extra 4,200 health visitors to "extend coverage of the Healthy Child Programme for all families, including the most disadvantaged' (DfE/DWP, 2011: 50). The same document also set out plans to double the number of families receiving the Family Nurse Partnership (FNP)service from 6,000 to 12,000 by 2015 (DfE/DWP, 2011: 38). The FNP service 'involves up to 64 structured home visits' and is aimed at first-time pregnant women aged up to 23 years (Robling et al, 2016). An update on the official FNP/NHS website in March 2015 highlights a further expansion in the numbers of families 'benefitting' from the service, whilst the largely discredited theory of a 'cycle of deprivation' (Brown and Madge, 1982; Gordon, 2011) is invoked as justification for the programme.

In 2013, the Government committed to increase the number of Family Nurse Partnership (FNP) places available in England at any one time from 11,000 to at least 16,000 by March 2015. With 135 local authorities across England now delivering the service, many of the most vulnerable young people will benefit, helping to break the cycle of deprivation for them and their babies.

This desire to intervene in private and domestic settings is, of course, not new. By way of example, prior to the 1880s in the UK, cases of child abuse and neglect often came to light in public places, and were largely dealt with by policemen. Following the establishment of the organisation that was later to become the National Society for the Prevention of Cruelty to Children (NSPCC), social workers would 'patrol slums' and follow children home who they suspected were being abused or neglected, referring to them as 'cruelties of the street' (Ferguson, 2011: 20). By the early 1900s, the 'home visit' had become an increasingly important practice in this area and this remains the case to this day. Family support workers have also worked in family homes, carrying out domestic work. The recent past has, however, also seen a 'retreat' from face-to-face practice and less time spent in family homes, 'in favour of an interprofessional communication agenda' (Ferguson, 2011: 38).

At around the same time that social workers were beginning to make home visits, health visitors were also beginning to knock on the doors of working class family homes in the UK. Women were employed in the expanding field of public health to ensure that houses were kept clean, safe and free of illness and disease. Again, this development shifted the focus of public policy interventions from spaces outside of the home and emphasised the need to get inside the family home in order to effect change. This process was repeated in the years following the Second World War when Family Service Unit workers worked in a practical hand-on way with the 'problem families' of the 1940s and 1950s (Starkey, 2000).

It is important to note that the increased reach of the state during these two periods (the late nineteenth century and the post Second World War period) was linked to and symbolic of a wider expansion of welfare-related activities. At the current time, the increased focus on interventions delivered inside the family home is occurring whilst wider welfare and social policy reforms are reducing support to disadvantaged groups and cutting public services. The Troubled Families Programme is the most high-profile example of the states extended reach into family life and family homes. 
p. 199. From the desk to the front-room? The changing spaces of street-level encounters with the state under austerity

\section{The Troubled Families Programme}

\section{Background and history}

The contemporary concern about a relatively small number of 'troubled families' who are 'the source of a large proportion of the problems in society' (Cameron, 2011a) represents the latest reconstruction of the 'underclass' thesis (Welshman, 2013). The belief that there is a group or class of people that exhibit different cultural values and norms from mainstream society is a longstanding one, in the UK and USA at least (Gans, 1995: 13) and has been documented extensively elsewhere (Jordan, 1974; Golding and Middleton, 1982; Dean and Taylor-Gooby, 1992; Morris, 1994; Macnicol, 1999; Welshman, 2013). Welshman (2013: 18) suggests that "the broad idea of an underclass dates back at least as far as the seventeenth century Poor Law, with its concerns about vagrancy, and desire to distinguish between deserving and undeserving claimants'. He notes that such ideas have reappeared periodically under slightly different labels (2013: 2) and documents the transitions from concerns about 'social residuum' in Victorian times, through concepts such as a 'social problem group in the 1930s and 'problem families' in the 1940s to more recent concerns about 'transmitted deprivation' (1970s), an 'underclass' (1980s), and the 'socially excluded' (2000s) before eventually arriving at today's 'troubled families'.

Shortly after being elected as Prime Minister, David Cameron announced a new programme - Working Families Everywhere - to get approximately 100,000 'troubled families' who had 'never worked' into employment (Cameron, 2010) using volunteer 'family champions', and headed on an unpaid basis by Emma Harrison, the Chief Executive of a private sector 'welfare-to-work' organisation (see Crossley, 2016a for a fuller discussion). Cameron (2010) argued that '[f]or years we've known that a relatively small number of troubled families are responsible for a large proportion of the problems in our society' and that, left unchecked, '[t]he problems get worse. The misery increases - for them, their neighbours and society as a whole'.

Following the riots that took place in towns and cities across England in 2011, Cameron (2011b) moved swiftly to lay the blame for the disturbances with absent parents or those who 'didn't much care' or had 'lost control':

I don't doubt that many of the rioters out last week have no father at home. Perhaps they come from one of the neighbourhoods where it's standard for children to have a mum and not a dad, where it's normal for young men to grow up without a male role model, looking to the streets for their father figures, filled up with rage and anger. So if we want to have any hope of mending our broken society, family and parenting is where we've got to start.

Cameron also promised 'more urgent action ... on the families that some people call 'problem', others call 'troubled' stating that he would 'clear away the red tape and the bureaucratic wrangling, and put rocket boosters' under the existing plans to 'turn around the lives of the 120,000 most troubled families in the country'.

\section{The Troubled Families Programme}

Four months later, in December 2011, Cameron announced the launch of a new government programme which replaced the volunteer-led approach of the Working Families Everywhere scheme. The TFP would "change completely the way government interacts' with 'troubled families' and advocated a 'family intervention model' (Cameron, 2011a) which sees a single key worker working intensively with the family 
p. 200. From the desk to the front-room? The changing spaces of street-level encounters with the state under austerity

and looking at it 'from the inside out, to understand its dynamics as a whole' (DCLG, 2012: 4). The TFP would be operated on a Payment by Results (PbR) model which would reward local authorities for specific and measurable changes in the behaviour of family members, such as increased school attendance, moving off out-of-work benefits or reduced involvement in crime or anti-social behaviours.

'Troubled families' were linked with drug addiction, alcohol abuse, crime and 'a culture of disruption and irresponsibility that cascades through generations' (Cameron, 2011a). The official criteria for being identified as a 'troubled family' included crime, anti-social behaviour, truancy or school exclusion, and unemployment (DCLG, 2012: 9). This centrally designed criteria, at a time of supposed local solutions, reduced, to some extent, the local discretion available to practitioners as to who was eligible for the TFP, although a fourth broader criterion of 'families who represent a high cost to the public purse' was also included.

Cameron sought to put distance between the TFP and the approach of the previous government. He suggested that part of the problem was the number of different welfare services that were often involved with families, suggesting that one family was involved with 28 different professionals (Cameron, 2011a). He argued that in contrast to the 'excess of unthinking, impersonal welfare' which left families 'swamped with bureaucracy' and 'smothered in welfare', the approach of the TFP would represent a fundamental change.

The shift from the 'impersonal' office, or the street-level, to the more personal or intimate space of the front door or the front room of the families is a key element of the rhetoric surrounding the TFP. At the launch of the programme, Cameron (2011a) stated that 'When the front door opens and the worker goes in, they will see the family as a whole and get a plan of action together, agreed with the family'. This imagery has been taken up by Louise Casey, the senior civil servant in charge of the TFP:

We have staff and workers who are extraordinary. They walk into these families' lives; they do not invite them to an office for an appointment with a letter. They walk through the front door and into the front room past two extraordinarily difficult and dangerous-looking dogs that they hope are locked in the kitchen. They have to sit on a settee, often in a pretty rough environment with some very aggressive people, and, with kids not in school and people all over the criminal justice system and so on .... I think that is extraordinary (House of Commons Committee of Public Accounts, 2014).

Casey has suggested that the family intervention model works precisely because it 'get[s] into the actual family, in their front room' (Casey, 2013) and has argued that the programme revolves around workers who 'have to be bold about getting past [troubled families] front doors' (quoted in Bond-Taylor, 2015), and who can 'keep the family's trust and then roll up their sleeves and get stuck in to offer practical help' (DCLG, 2012: 4). The programme is, Casey believes, about getting down on hands and knees to help families 'scrub floors' (Bennett, 2012) and 'about sitting on [troubled families] settees' (BBC, 2012). Elsewhere, and suggesting a state-sponsored game of musical chairs, Eric Pickles, the Government Minister in charge of the first phase of the TFP, stated that the programme was about 'getting [troubled families] off the sofa of despair' (Pickles, 2014, emphasis added).

The 'family workers' involved with the TFP have thus been positioned against other street-level bureaucrats, such as those who invite citizens 'to an office for an appointment', with social workers coming in for particular criticism from Casey. She has argued that many social workers 'are simply circling around the families, assessing them and prodding them' (BBC, 2012) and just 'turn up with clipboards', simply 
p. 201. From the desk to the front-room? The changing spaces of street-level encounters with the state under austerity

'monitor decline' but 'don't actually make any difference' (quoted in Bennett, 2012: 15). The TFP, in contrast, is portrayed as not 'some cuddly social worker's programme to wrap everybody in cotton wool' (quoted in Winnett and Kirkup, 2012).

The positioning of the 'family intervention' model against other forms of service delivery is not new. Parr and Nixon (2008) highlight how, under New Labour, FIPs were identified as 'pioneering projects' and as an innovative response to the inability of traditional family services to 'get to grips' with anti-social or 'problem' families. They have also been described as 'sites of social work practice' (Parr, 2009) where it is possible for workers to exercise professional discretion and 'engage in the kind of creative practice that proceduralization, bureaucracy and managerialism have made impossible to achieve in mainstream social work arenas' (Parr, 2009: 1257). The outcomes driven $\mathrm{PbR}$ model of the TFP, and the requirement to see specific and rapid behaviour change relating to the household, potentially afford little room for such opportunities. For example, Bond-Taylor (2015) has highlighted how practitioners who want to work in an 'empowering' way sometimes slip into a responsibilizing approach due, in part, to the constraints of the programme.

There have been a number of criticisms of the 'family intervention' approach (Garrett, 2007; Gregg, 2010) and it is doubtful that the TFP has been anything like the near-perfect success that the government claims it has been (DCLG, 2015; see Bawden, 2015 and Crossley, 2015 for critiques of this success). It is also unlikely, given what we know about street-level bureaucracy that the day-to-day conduct of the programme is the same as the central government portrayal of it. But the focus here is not on the daily complexity that surrounds implementation, but on the spaces in which the programme putatively operates and the symbolic and political work that this spatial imagery performs. The next section highlights the ways in which the discourse of the 'front door' serves to assist the wider re-crafting of the state in the UK, with the 'family intervention' model indicative of a new way of working that has become 'fiercely interventionist' (Wacquant, 2009: 308) in the lives of 'troubled families', even under austerity.

\section{Discussion}

The focus on the close-up intimate nature of the interactions between family workers and members of 'troubled families' in the domestic space of the home performs a number of symbolic and political functions. It enables wider structural determinants and issues to remain undiscussed. The family's 'troubles' are effectively depoliticized. This rhetorical focus on personal and familial behaviour leaves little room for discussion (including amongst family members themselves) about the structures which affect and influence family life and individual agency - the quality and supply of housing, the availability of good, secure employment and the physical and mental health impacts associated with the lack of both. The impact of the government's welfare reforms on these families is left 'outside' of the remit of the TFP and is portrayed as largely benign. The ability of workers to 'get in through the front door' also renders the withdrawal of the state from its more traditional locales as inconsequential. The emphasis on practical, hands-on support that takes place in the family home similarly helps to shift attention away from the potential for material support from the state which, as we have seen, is reducing. Administrative work and assessments of families, which could include ensuring families are receiving all of the support (financial or otherwise) they are entitled to, are ridiculed in the TFP narrative, where a willingness to 'don the marigolds' is afforded primacy. 
p. 202. From the desk to the front-room? The changing spaces of street-level encounters with the state under austerity

The alleged practical and 'domestic' nature of the work - helping children get ready for school, cooking meals, cleaning the house, ensuring personal hygiene standards are maintained and establishing bed-time routines for children where appropriate symbolically draws attention to the role of mothers in 'troubled families'. The physical, muscular 'full on intense approach' (Casey, 2013) of the TFP thus identifies a strong paternalistic intervention as the solution to the perceived problem of maternal failings or incompetence.

These symbolically potent encounters between the state worker and members of the family thus become, in Bourdieu's words, examples 'of those cases where the visible, that which is immediately given, hides the invisible which determines it' (Bourdieu, 1989: 16). All of the above points help the government to draw a symbolic distinction between an old, failing system of administering welfare to disadvantaged families and a new dynamic, pro-active system embodied in the TFP.

DuBois (2010: 183) has argued that:

Undoubtedly, no figure is more prone to prejudice than the 'civil servant' behind his desk: the almost absurd artificiality of the rules they enforce and the rigidity of their world of administrative forms seem to call for mockery or revolt.

In the place of the constrained, desk-bound civil servant, then, comes, via the TFP, a new breed of bureaucrats, characterised by their 'persistent, assertive and challenging' approach, and their ability to 'get in through the front door', 'get stuck in' and show 'troubled families' how to set boundaries and routines for their wayward offspring. The state is being remade and Cameron's (2011a) argument at the launch of the TFP that it was necessary to "change completely the way government interacts with [troubled families]; the way the state intervenes in their lives' is being made good.

The TFP, which Cameron (2016) recently claimed was 'perhaps the most intensive form of state intervention there is', can thus be viewed as being at the vanguard of the crafting of a neoliberal state (Crossley, 2016b). Plans to extend the intensive keyworker approach to different groups have been mooted both inside government (Cameron, 2015) and by think-tanks (McNeil and Hunter, 2015). As the ideal of the universal 'welfare state', displayed in public spaces, is rolled back under austerity, a new, more targeted and interventionist 'hands-on' state is symbolically rolled out (Wacquant, 2009: 304) into the private dwellings of 'troubled families'. In this scenario, public buildings and other spaces where public services were traditionally delivered are no longer required. Instead, a smarter state, which sets it sights on working with only the 'most disadvantaged' (DfE/DWP, 2011) or, in Casey's words, the 'worst families' (quoted in Hellen, 2014), makes use of data to identify 'troubled families' before sending 'troubleshooters' (Cameron, 2011) out to their homes to engage with them and 'turn them around' with minimal bureaucratic support.

Further reductions in local government funding are planned and the government's welfare reforms and wider re-structuring will continue to impact on poor and disadvantaged groups, especially families with children (Beatty and Fothergill, 2016). It is likely that local authority services will again be forced to rationalise their activities, reduce their client base, change location or close altogether. At precisely the same moment, the TFP is being rolled out to an extra 400,000 families, with more relaxed criteria which potentially include almost any families who are referred in to nonuniversal services (Crossley, 2016a). The same groups identified as the clearest losers' by De Agostini et al (2015) of the government's tax and benefit reforms coincidently happen to be the main 'beneficiaries' of the new state that is being crafted (Wacquant, 2009: 305). 
p. 203. From the desk to the front-room? The changing spaces of street-level encounters with the state under austerity

\section{Conclusion}

The physical, everyday, 'street-level' spaces where this newly crafted state operates where it appears afresh and reinvigorated, and where it has withdrawn from - deserve greater scrutiny than they have had to date. What is certain is that we should not accept the government's drawing of the line around the family home as the site where 'troubled families' circumstances can best be both explained and improved. Testimonies from the families and street-level bureaucrats involved in the complex reality of the daily life of the TFP will be important here.

Events that take place within the four walls of the family home can never fully explain what happens there. Events that take place in other spaces also affect the lives of disadvantaged families, and these deserve and indeed require investigation. For example, it is very possible that the truth of 'troubled families' lives might more adequately be explained by encouraging family workers to get through some front doors in Westminster, examining the decisions, behaviours and norms of the people who reside and work there. These workers who have purportedly 'turned around' 99 per cent of the 'troubled families' they have worked with could, perhaps, be better employed working with some 'troubled politicians', for:

If these skills really exist, surely they are wasted upon obscure members of the British working classes: would not the case-workers do better to get their hands on some of our world's rulers? (Wootton, 1959: 253)

*Correspondence address: Stephen Crossley, Room G210, Coach Lane Campus (East), Northumbria University, Newcastle upon Tyne, NE7 7XA, United Kingdom. Email: stephen.crossley@northumbria.ac.uk

\section{References}

Bawden, A. (2015) Is the success of the government's troubled families scheme too good to be true? The Guardian, [online] Available at: http://www.theguardian.com/society/2015/nov/11/troubled-family-programmegovernment-success-council-figures [Accessed: 04/05/16].

BBC (2012) Louise Casey calls for new approach on 'troubled families'. BBC, [online] Available at: http://www.bbc.co.uk/news/uk-politics-18881046 [Accessed: 03/11/15].

Beatty, C. and Fothergill, S. (2016) The uneven impact of welfare reform: The financial losses to places and people. CRESR, Sheffield Hallam University.

Bennett, R. (2012) Local Authority Officials 'should scrub floors.' The Times, 27 April 2012: 15.

Bond-Taylor, S. (2015) Dimensions of Family Empowerment in Work with So-Called 'Troubled' Families. Social Policy and Society, 14, 3, 371-384.

Bourdieu, P. (1989) Social space and symbolic power. Sociological Theory, 7, 1, 14-25.

Bourdieu, P., Accardo, A., Balazs, G., Beaud, S., Bonvin, F., Bourdieu, E., Bourgois, P., Broccolochi, S., Champagne, P., Christin, R., Faguer, J.P., Garcia, S., Lenoir, R., OEuvrard, F., Pialoux, M., Pinto, L., Podalydès, D., Sayad, A., Soulié, C. and Wacquant, L. (1999) The weight of the world: Social suffering in contemporary society. Stanford, CA: Stanford University Press.

Brown, M. and Madge, N. (1982) Despite the welfare state: DHSS Studies in Deprivation and Disadvantages. London: Heinemann.

Butler, P. (2014) A third of councils cut 'meals on wheels' elderly care lifeline. The Guardian, [online] Available at: https://www.theguardian.com/society/patrick- 
p. 204. From the desk to the front-room? The changing spaces of street-level encounters with the state under austerity

butler-cuts-blog/2014/nov/11/third-councils-cut-meals-on-wheels-social-care [Accessed: 30/08/16].

Cameron, D. (2010) Speech on families and relationships. Available at: https://www.gov.uk/government/speeches/speech-on-families-and-relationships [Accessed: 02/02/14].

Cameron, D. (2011a) PM's speech on the fightback after the riots. Available at: https://www.gov.uk/government/speeches/pms-speech-on-the-fightback-afterthe-riots [Accessed: 02/0/14].

Cameron, D. (2011b) Troubled families speech. Available at: https://www.gov.uk/government/speeches/troubled-families-speech [Accessed: 02/02/14].

Cameron, D. (2014) Speech at the Relationships Alliance Summit. Available at: https://www.gov.uk/government/speeches/david-cameron-on-families [Accessed: 03/11/15].

Cameron, D. (2015) Prime Minister: My vision for a smarter state. Available at: https://www.gov.uk/government/speeches/prime-minister-my-vision-for-asmarter-state [Accessed: 03/11/15].

Cameron, D. (2016) Prime Minister's speech on life chances. Available at: https://www.gov.uk/government/speeches/prime-ministers-speech-on-lifechances [Accessed: 11/05/16].

Casey, L. (2013) Former Portsmouth police officer back on ASBO beat. Available at: www.bbc.co.uk/news/uk-england-hampshire-23896776 [Accessed: 03/11/15]

Crossley, S. (2015) The Troubled Families Programme: the perfect social policy? Centre for Crime and Justice Studies, Briefing 13. Available at: http://www.crimeandjustice.org.uk/sites/crimeandjustice.org.uk/files/The\%20Tr oubled\%20Families\%20Programme\%2C\%20Nov\%202015.pdf [Accessed: 30/08/16].

Crossley, S. (2016a) The Troubled Families Programme: in, for and against the state? In: M. Fenger, J. Hudson \& C. Needham (eds) Social Policy Review 28: Analysis and Debate in Social Policy. Bristol: Policy Press.

Crossley, S. (2016b) 'Realising the (troubled) family', 'crafting the neoliberal state'. Families, Relationships and Societies, 5, 2, 263-279.

Davies, J. (2013) The public library service under attack: how cuts are putting individuals and communities at risk and damaging local businesses and economies. London: UNISON. Available at: https://www.unison.org.uk/content/uploads/2013/06/On-lineCatalogue215893.pdf [Accessed: 31/08/16].

DCLG (2012) Working with Troubled Families: a guide to the evidence and good practice. London: DCLG.

DCLG (2015) PM praises Troubled Families success. Available at: https://www.gov.uk/government/news/pm-praises-troubled-families-programmesuccess [Accessed 17/09/16]

De Agostini, P., Hills, J. and Sutherland, S. (2014) Were we really all in it together? The distributional effects of the UK coalition government's tax-benefit policy changes, Social Policy in a Cold Climate Working Paper 10. Centre for Analysis of Social Exclusion. Available at: http://sticerd.Ise.ac.uk/dps/case/spcc/wp10.pdf [Accessed: 31/08/16].

Dean, H. and Taylor- Gooby, P. (1992) Dependency Culture: The Explosion of a Myth Hemel Hempstead: Harvester Wheatsheaf.

DfE/DWP (2011) A New Approach to Child Poverty: Tackling the Causes of Disadvantage and Transforming Families' Lives. London: The Stationery Office.

DWP (2015) Policy paper: 2010 to 2015 government policy: welfare reform. London: Department for Work and Pensions. Available at: https://www.gov.uk/government/publications/2010-to-2015-government-policy- 
p. 205. From the desk to the front-room? The changing spaces of street-level encounters with the state under austerity

welfare-reform/2010-to-2015-government-policy-welfare-reform 20 October 2015 [Accessed 0311/2015]

DuBois, V. (2010) The Bureaucrat and the Poor: Encounters in French Welfare Offices. Abingdon: Routledge.

Ferguson, H. (2011) Child Protection Practice, Basingstoke: Palgrave Macmillan

Fletcher, D. (2011) Welfare Reform, Jobcentre Plus and the Street-Level Bureaucracy: Towards Inconsistent and Discriminatory Welfare for Severely Disadvantaged Groups? Social Policy and Society, 10, 4, 445-458.

Fox Piven, F. and Cloward, R. (1977) Poor People's Movements: Why They Succeed, How They Fail. New York: Pantheon.

Gans, H. (1995) The War Against the Poor: The Underclass and Antipoverty Policy. New York: Basic Books.

Garrett, P. (2007) 'Sinbin' solutions: the 'pioneer' projects for 'problem families' and the forgetfulness of social policy research. Critical Social Policy, 27, 2, 203-30.

Golding, P. and Middleton, S. (1982) Images of Welfare: Press and Public Attitudes to Poverty. Oxford: Martin Robertson.

Gordon, D. (2011) Consultation response: Social mobility and child poverty review. Available at: www.esrc.ac.uk/ images/PSE social mobility tcm8-18436.pdf [Accessed: 05/06/14].

Gregg, D. (2010) Family intervention projects: a classic case of policy-based evidence. London: CCJS. Available at: https://www.crimeandjustice.org.uk/sites/crimeandjustice.org.uk/files/family\%2 Ointervention.pdf [Accessed: 30/08/16]

Harrison, M. and Sanders, T. (2015) Social policies and social control: New perspectives on the 'not-so-big society'. Bristol: Policy Press.

Hastings, A., Bailey, N., Bramley, G., Gannon, M. and Watkins, D. (2015) The cost of the cuts: the impact on local government and poorer communities. York: Joseph Rowntree Foundation.

Hayden, C. and Jenkins, C. (2014) 'Troubled Families' Programme in England: ‘wicked problems' and policy-based evidence. Policy Studies, 35, 6, 631-649.

Hellen, N. (2014) Rise of new underclass costs £30bn. The Sunday Times, 17 August 2014.

House of Commons Committee of Public Accounts (2014) Programmes to help families facing multiple challenges, Fifty-first Report of Session 2013-14. London: The Stationery Office.

Hupe, P., Hill, M. and Buffett, A. (2015) Understanding street-level bureaucracy. Bristol: Policy Press.

Innes, D. and Tetlow, G. (2015) Central cuts, local decision-making: Changes in local government spending and revenues in England, 2009-10 to 2014-15, IFS Briefing Note BN166. London: Institute for Fiscal Studies.

Jordan, B. (1974) Poor parents. London: Routledge.

Lipsky, M. (1980) Street-Level Bureaucracy: Dilemmas of the Individual in Public Services. New York: Russell Sage Foundation.

Lupton, R. and Fitzgerald, A. (2015) The Coalition's record on Area Regeneration and Neighbourhood Renewal 2010-2015. Social Policy in a Cold Climate Working Paper 19, Centre for Analysis of Social Exclusion. Available at: http://sticerd.Ise.ac.uk/dps/case/spcc/wp19.pdf [Accessed: 31/08/16].

Macnicol, J. (1999) From 'problem family' to 'underclass' 1945-95. In: H. Fawcett and R. Lowe (eds) Welfare policy in Britain: The road from 1945. Basingstoke: Macmillan, 69-93.

McNeil, C. and Hunter, J. (2015) Breaking boundaries: Towards a 'Troubled Lives' programme for people facing multiple and complex needs. Available at: http://www.ippr.org/files/publications/pdf/breakingboundaries Sep2015.pdf?noredirect=1 [Accessed: 05/05/16]. 
p. 206. From the desk to the front-room? The changing spaces of street-level encounters with the state under austerity

Morris, L. (1994) Dangerous classes: The underclass and social citizenship. London: Routledge.

Parr, S. (2009) Family Intervention Projects: A Site of Social Work Practice. British Journal of Social Work, 39, 7, 1256-1273.

Parr, S. and Nixon, J. (2008) Rationalising family intervention projects. In: Squires, P. (ed.) ASBO nation: The criminalisation of nuisance. Bristol: The Policy Press, 161179.

Pickles, E. (2014) Eric Pickles' speech to the National Conservative Convention. Available at: http://press.conservatives.com/post/82077378511/eric-picklesspeech-to-the-national-conservative [Accessed: 03/11/15].

Puffett, N. (2016) More than 1,000 children's centres axed since 2010. Children and Young People Now [online] Available at: http://www.cypnow.co.uk/cyp/news/1156991/more-than-1-000-children-scentres-axed-since2010?utm content $=$ \&utm campaign $=260416 \% 20$ Daily $\% 20$ Bulletin\&utm sourc e=Children\%20\&\%20Young\%20People\%20Now\&utm_medium=adestra_email\&u tm term=http://www.cypnow.co.uk/cyp/news/1156991/more-than-1-000children-s-centres-axed-since-2010 [Accessed: 11/05/16].

Robling, M., Bekkers, M-J., Bell, K. et al. (2016) Effectiveness of a nurse-led intensive home-visitation programme for first-time teenage mothers (Building Blocks): a pragmatic randomised controlled trial. The Lancet, 10028, 387, 146-155.

Starkey, P. (2000) The feckless mother: women, poverty and social workers in wartime and post-war England. Women's History Review, 9, 3, 539-57.

Taylor, M. (2015) 'Vast social cleansing' pushes tens of thousands of families out of London. The Guardian, [online] Available at: http://www.theguardian.com/uknews/2015/aug/28/vast-social-cleansing-pushes-tens-of-thousands-of-familiesout-of-Iondon [Accessed: 03/11/15].

Taylor-Gooby, P. (2012) UK heading for bottom place on public spending [online] Available at: http://www.poverty.ac.uk/articles-government-cuts-internationalcomparisons-public-spending-whats-new/uk-heading-bottom-place [Accessed: 03/11/15].

UNISON (2014) The UK's youth services how cuts are removing opportunities for young people and damaging their lives. UNISON. Available at: https://www.unison.org.uk/content/uploads/2014/07/On-lineCatalogue225322.pdf [Accessed: 30/08/16].

Wacquant, L. (2008) Urban outcasts: A comparative sociology of advanced marginality. Cambridge: Polity Press.

Wacquant, L. (2009) Punishing the Poor: The Neoliberal Government of Social Insecurity. Durham and London: Duke University Press.

Wallace, A. (2010) Remaking Community? New Labour and the Governance of Poor Neighbourhoods. Farnham: Ashgate.

Welshman, J. (2013) Underclass: A History of the Excluded Since 1880 (2nd edition). London: Bloomsbury.

Winnett, R. and Kirkup, J. (2012) Problem families have 'too many children'. The Telegraph, [online] Available at: http://www.telegraph.co.uk/news/politics/9416535/Problem-families-have-toomany-children.html [Accessed: 30/08/16].

Wootton, B. (1959) Daddy Knows Best. The Twentieth Century, 166, 248-261. 